DOI https://doi.org/10.18551/rjoas.2016-12.25

\title{
BORROWER CHARACTERISTICS AND RELATIONSHIP LENDING ON LENDING DECISION MAKING: A SURVEY OF LITERATURE
}

\author{
I Gde Kajeng Baskara* \\ Faculty of Economics and Busines, University of Udayana, Indonesia \\ Ubud Salim, Djumahir, Atim Djazuli \\ Faculty of Economics and Business, University of Brawijaya, Indonesia \\ `E-mail: kajengbaskara@yahoo.com, kajengbaskara@unud.ac.id
}

\begin{abstract}
The purpose of this article was to explore and analyze the earlier findings and latest research-related on lending decision making. The review focuses on the borrower characteristic information and relationship lending on lending decision making. Previous research revealed that the borrower characteristic information produced through the socalled lending technology, and the characteristics of the borrower can be classified into two categories; qualitative characteristic and quantitative characteristics. The results of this review also showed that there were inconsistencies findings on the effects of the characteristics of the borrower and relationship lending on lending decision making. These finding inconsistencies allegedly influenced by organizational factors and banks loan officer psychological factors as decision makers in the lending decision making.
\end{abstract}

\section{KEY WORDS}

Lending decision making, borrower's characteristic, relationship lending, lending technology.

Financial intermediation theory states that the intermediary institution is the link that bridges the underfunded and those who need funds. The process of financial intermediation occurs when there is an imbalance situation of information between surplus and deficit (Leland and Pyle, 1977; Diamond, 1984; Fama, 1985; Diamond, 1991; Greenbaum and Thakor, 2007). To overcome this situation required intermediary institutions as intermediaries to solve the inequity in information or asymmetry information problem.

Bank is an institution to perform the function of financial intermediation. In its efforts to distribute the loan, banks rely on loan officers' role in taking decisions regarding the feasibility of a loan. In the lending decision making, loan officers rely on information and relationships with borrowers. How the role of borrowers characteristics information and relationship lending in the lending decision making, becomes the main question of this study. Analyze the past and recent research and concepts, as well as empirical studies on this theme became the main dish of this survey of literature. The main purpose of this article is to trace and analyze the concepts and the latest findings on the role of the borrower characteristics and relationship lending in making lending decisions.

Previous literature review on lending decision making is focused on a different part of the lending process, such as the impact of credit scoring (Hand and Henley, 1997), the impact of relationship lending (Elyasiani and Goldberg, 2004; Boot, 2000) and the role of intangible factors in making lending decisions (Canibano et al., 2000). Only two reviews focused on studies related to the role of loan officers and individual decision making (Andersson, 2000; Maines, 1995). A special review highlights the psychological factor of banker's on lending decision making (Tronberg and Hemlin, 2012).

This article will be presented as following structures, first will be presented search related research in the lending decision making, then the second part presented research that examines the borrower characteristic on lending decision making, the third part concerns the relationship lending on lending decision making and the last will be presented conclusion 
that also outlines further research that will be needed to complete the understanding of this issue.

Lending Decision Making. In an effort to understand more about the lending decision making is inseparable from research studies related decision making. The most influential study in decisions on economics and finance is studied on heuristics and biases in decision making by Tversky and Kahneman (1974) as well as prospect theory (Kahneman and Tversky, 1979). Both research revealed that any decision by an individual is often a cognitive error. These errors include being too risk averse and overstating small probabilities (Kahneman et al., 1982).

The findings of this research and human weaknesses in decision making was questioned and deepened by the paradigm of naturalistic decision making (NDM) (Klein, 2008; see also Gigerenzer, 2007). If the research on Heuristics and Biases Paradigm (HBP) focuses on human weaknesses in the decision to use cognitive processes, research on NDM revealed that in a real situation, the cognitive process can produce the right decision (Klein, 2008). Several experimental studies have shown that cognitive processes, including the use of intuition in decision making can produce the right decision (Dijksterhuis and Nordgren, 2006; Nordgren and Dijksterhuis, 2009), but other research found that cognitive processes with this intuition does not always result in a decision that is valid and right (Newell and Rakow, 2011; Newell et al., 2009).

The findings of this research bring this review to the concept of situational influence on decision making. This theory states that the decisions affected and are guided by the role of the existing situation (Simon, 1955, 1956). The academics slightly overlook the important role in decision-making situations (Gigerenzer, 2007; Hogarth and Karelaia, 2007). Recent research suggests that successes in using intuition on cognitive processes are very dependent on the validity of the situation faced by decision makers (Kahneman, Klein, 2009).

Various explanations show that decision-making is very complex. There is a cognitive process and intuition as well as the importance of the role of the situation at the time of decision making. This concept also applies to the lending decision making regarding the financial outcome prediction. Lending decision making is very dependent on cognitive processes, and the role of the situation at the time of decision making. At the bank, loan officer plays an important role in the lending decision making. Loan officer's using certain methods in the lending decision making. The quantitative methods involve factors, such as financial statement lending, asset-based lending and credit scoring (Berger and Udell, 2006). In addition, loan officers also use qualitative methods in lending decision making, this method involves gathering information qualitative characteristics of the borrower such as personal characteristics (Bealieu, 1996; Soares, et al., 2011), the family situation and environment (Sutter, 2007; Elyasiani and Goldberg, 2004; Elsakit and Worthington, 2012), management capability as well as business and marketing (Soares et al., 2011; Grunert et al., 2005).

A recent studies show the methods of collecting information that used by loan officer in the lending decision making is classified into two categories, transactional lending technology and relationship lending technology (Tronberg and Hemlin, 2012). The information collected by loan officers is related to the characteristics of the borrower. In this article, information about the borrower characteristic will also be classified into two characteristics that call qualitative and quantitative characteristics. The qualitative characteristics include soft information of the borrower (Udell, 2007; Petersan, 2004) such as personal characteristics, environment, family, and business management capabilities as well as marketing, where the collection of this information tends to use a method of relationship lending technology. In contrast the quantitative characteristics includes hard information is based on financial statements information, collateral, credit scoring and quantitative information on other (Udell, 2007; Petersan, 2004; Grunert et al., 2005, Soares et al., 2011) obtained through transactional lending technology. The following review will be explored previous research that examines the role of borrower characteristic (qualitative and quantitative) in conjunction with the lending decision making.

Borrower Characteristics and Lending Decision Making. Study about the borrower characteristics and lending decision making is not only found in the banking sector, 
especially financial intermediation, but also many on the study of accounting, financial management and entrepreneurship. At the beginning, the conventional banking literature introduces the 5Cs conceptual framework in the analysis of creditworthiness. The 5Cs are character (ie evaluation of the prospective borrower's personal characteristics), capital (i.e. the borrower's net worth), collateral (i.e. the borrower's pledge of property to secure the debt), capacity (ie the borrower's ability to service the debt out of current income), and conditions (i.e. the present market conditions for both the borrower and the general economy) (Crigger, 1975; Beaulieu, 1996; Thomas, 2000). In evaluating the prospective borrower, the $5 \mathrm{Cs}$ should be given equal emphasis. The $5 \mathrm{Cs}$ should help loan officers focus on relevant information and thereby help to ensure they make an objective assessment of the client.

In the year 2000, the Bank for International Settlements (BIS) published a standard practice the so-called Basel Accord. This practice should be followed in the global banking feasibility analysis and credit monitoring. The rule provides that banks in lending decision and monitoring of credit should base on statistical methods, as well as consideration based on skills and experience. Refers to this system the bank in its analysis is required to use both qualitative and quantitative characteristics of the borrower. These characters include, leverage, profitability and liquidity ratios, management experience and industry perspective of the borrower and its business (Grunert et al., 2005). The literature in banking and finance then reconstructs classification of $5 \mathrm{C}$ characteristic is only being two categories of characteristics that are qualitative (soft information) and quantitative characteristics (hard information) (Udell, 2007). Research conducted by Petersen (2004) introducing the concept of soft and hard information, and put forward ideas, how banks can better quantify the qualitative characteristics information of their customers (hardening the soft information).

Asymmetry of information is the most important thing in the process of financial intermediation. Preliminary research related information, and banking conducted by Hodgman (1961), Diamond (1984), and Petersen (2004). Studies on the reliability of information in the financial intermediation were conducted by Ramakrisnan and Thakor (2006). Qualitative information or "soft" information in the form of a personal character, ability or skill, honesty, social behavior, culture, family and their neighborhood (Petersen, 2004). This qualitative information obtained through relationship lending technology (Udell, 2007). Qualitative information will be used by loan officers in view of the qualitative character of the borrower.

In addition to soft information in the lending technology, there is also "hard" quantitative information. Hard information is related to the borrower's financial information, whether obtained through the financial statements, as well as collecting information directly linked the borrower's financial such as financial statements, collateral assets, business flow, capital, etc. (Petersen, 2004). The information acquired through statistical data also includes quantitative information. Quantitative information was obtained through a mechanism commonly called transactional lending technology.

Petersen (2004) stated that in accordance with developments in technology, hard information will dominate the borrower-related information for ease of transfer mechanism and preparation. Quantitative information (hard) is also easily comparable (comparable). The briefly dichotomy between soft and hard information will be reflected on the characteristics of borrowers. Qualitative characteristics reflected in the soft information, whereas quantitative characteristics from hard information.

The accounting literature classified the information related to borrowers' characteristic into two i.e. non-accounting information and accounting information. The study that observed the use of accounting information in lending decision making conducted by Danos, et al., (1989). This experimental study found that loan officer's confidence will increase after they have accounting information related to the borrower. A research was conducted by Price (1992) revealed that the quantitative characteristics such as accounting and financial information affect the creditworthiness. Quantitative characteristics of the borrower such ratios in the financial statements are used comprehensively by loan officers. The better the quantitative characteristics of the borrower will improve their creditworthiness. 
In a study that investigating which information is more influential to the loan officer when evaluating clients, Bruns and Fletcher (2008) found that the historical financial information of the borrower is the most important factor. The second important factor is the financial position of the borrower, which is based on how well the company compared to other companies. A less important factor is the competence of the borrower in the project business and the collateral provided. According to Mason and Stark (2004) bankers tend to analyze based on information collected from the previous financial records, compared to information about the issues of the capital market or the condition of human resources in a company. By measuring what is considered important information when making the decision to bankers and investors, the study reveals there is a difference between bankers and investors. Bankers are more interested in financial information while investors' emphasis on external factors such as market position. Therefore, it can be concluded that the bankers are more focused on the historical financial information of the capital market information into consideration when making lending decisions.

Research conducted by Beaulieu (1996) found that the accounting information and the information of borrower's personal character affect lending decisions. This study concluded at the time of accounting information is negative; the loan officer will not use the personal character information borrowers. However, at the time of accounting information is positive, personal character-related information will influence the lending decisions (Beaulieu, 1996). According to this research it is proved that the quantitative characteristics would take precedence in the analysis of creditworthiness. The use of non-financial factors in lending decision making were performed by Grunert, et al. (2005). This study concluded that the use of non-financial and financial information jointly in the analysis of creditworthiness and monitoring of internal credit rating can improve the accuracy in the estimation of the feasibility and predictive defaulted borrowers.

Study in Italy found empirical evidence that the use of qualitative and quantitative characteristics of the borrower's information should complement rather than replace each other (substitutability) in an effort to better accuracy on creditworthiness analysis (Bartoli, et al., 2013). This study confirms that the qualitative and quantitative characteristics are used together in the analysis of creditworthiness. The different result was presented by Soares et al., (2011). This study was trying to see the importance of each quantitative and qualitative characteristic criterion that must be considered by the loan officer when performing analyzes. By using respondents at six major banks in Portugal, this study using Multi-Criteria Decision Analysis (MCDA) as a method to look at different levels of interest on each criterion. Criteria used according to the criteria used in the Basel Accord such as the financial criteria, managerial capabilities and potential of the company (marketing). The results showed that the criteria for qualitative characteristics have a higher interest than the quantitative characteristics in looking at the feasibility of a loan (Soares et al., 2011). In a review conducted by Andersson (2000), reveal that although the financial information is important, but the personal characteristics are also important (Buttner and Rosen, 1988).

Wilson et al. (2007) investigated the decision-making of loan officers by asking them to recall the personal characteristics that they find most influential when evaluating creditworthiness. The research found that, when making lending decisions, the most influential information is information about a loan applicant's personal characteristics (eg. The applicant pleasant), while the financial information (i.e. Net income applicants) felt less important.

In summary, it can be concluded that studies evaluating the effect of the borrower's quantitative characteristics on lending decision making showed that the quantitative characteristics such as accounting and financial information has a significant influence on the creditworthiness in lending decision making (Danos et al., 1989; Beaulieu, 1996; Price, 1992; Grunert, et al., 2005; Bruns and Fletcher, 2008; Soares et al., 2011; Bartoli et al., 2013). The results on the influence of qualitative characteristics on lending decision making also show the same thing (Beaulieu, 1996; Boot, 2000; Wilson et al., 2007; Soares et al., 2011; Bartoli et al., 2013; Buttner and Rosen, 1988) 
Inconsistent findings of the study on the effects of the qualitative characteristics on lending decision making are the research conducted by Catasus and Grojer (2003) as well as Tornberg and Hemlin (2013). Catasus and Grojer (2003) showed that non-financial information, such as information on human resources, advertising and $R$ \& $D$ did not affect the loan officers in lending decision making. Tornberg and Hemlin (2013) found that loan officers encountered considerable difficulty in making a credit decision if it involves qualitative characteristics soft information such as personal character, social and environmental conditions, as well as relationship management capabilities.

Studies that examined the relationship between bank sizes with borrower information characteristic found the same thing. Research conducted by Campanella et al. (2013), and Uchida et al. (2012) found that the major banks, although it also uses qualitative characteristics of information, but this information is usually not a major concern, because the loan officers at large banks are accustomed to using quantitative information that is easier to collect. This finding is in line with the study by De La Torre et al. (2010) of the World Bank found that soft information such as the qualitative characteristics of the borrower is not a major concern in the lending decision making especially for borrowers with micro, small and medium enterprises category.

Literature reviews that conducted by Tronnberg and Hemlin (2013) concluded that in the lending decision making, both borrower's qualitative and quantitative characteristics collected through lending technology is indeed a big impact. However, based on previous research source, which of these two types of information is more influential in the lending decision making cannot be drawn any definitive conclusions. That study also concluded that there is a role of loan officer's psychological factors in lending decision making.

The studies on previous research have led to the conclusion that the borrower characteristics both qualitative and quantitative have a major impact and influence on lending decision making. However, in some studies the impact and influence proved insufficient impact on certain conditions and situations. The conditions and the situation among others is the psychological condition of the loan officer, the category of the type of credit proposed, a business group of borrowers (micro, small, medium or large) as well as a category on the relevant bank (big bank or a small bank).

Relationship Lending and Lending Decision Making. Information regarding borrower's characteristics that produced by the banks through loan officers, which became a kind front man bank in digging up information. In an effort to reduce the inequality of information, intermediary institutions such as banks need an intensive process to build a relationship with borrowers. In the banking concept study is usually called relationship banking or lending relationship.

Arnaud Boot (2000) defines relationship banking focused on two things which are proprietary information or information that is private and multiple interactions, or interactions that occur repeatedly and in a variety of products. According to Gregory Udell (2007), relationship lending is a method of analysis based on the collection of borrower's soft information. This is a qualitative and information collected by the bank from time to time through intense interaction with borrowers, including the use of various bank products by the customer.

Relationship lending is the borrower and lender interactions that are repeated and so closely established relationship between the two parties (Uchida et al., 2012). In a pattern of this kind of relationship the benefits not only are obtained by the borrower, but also the lenders in its efforts to collect information related to the borrower. The theory of the relationship lending based on the close relationship between lender and borrower to benefit economically. Some of the literature focuses on the consequences of this relationship on the lending decision making among others, such as creditworthiness, loan pricing, and the availability of credit or on decisions to be taken at the time of the borrower's bank experiencing difficulties in repayment (Elsas, 2002). A complete review literature on relationship lending can be found in the article composed by Boot (2002).

This review will specifically trace and analyze research related to relationship lending in relation to the lending decision making. Searches focused on the influence of relationship 
lending in the lending decision making. Research conducted by Petersen and Rajan (1994) found that the close and intense relationship between borrower and lender will be able to increase the availability of credit in the long term. Likewise, the study conducted by Berger and Udell (1995) found that the availability of funding and the interest rate loans generally gets better as a result of long-term relationships between banks and borrowers.

The study related to the relationship between relationship lending with the availability of credit for many borrowers focusing on credit approval, loan extensions and a lower cost of funds. Petersen and Rajan (1994) found that relationship lending increases the availability of credit to small businesses in America. Berger and Udell (1995) using the same data and found a link between relationship lending with the approval of top-up or extension of credit to the small business. The study also found that the long time effect on credit supply linkages between the credit contract agreement with the interest rate.

Jimenez and Saurina (2004) suggested that the close relationship between the loan officer with the borrower have a higher default risk than a distant relationship. This indicates there is a negative influence by relationship lending on lending decision making. Similar findings exist in research Degryse and Van Cayseele (2000), who found that the close relationship between banks and borrowers can increase the likelihood of loan approval, decline in demand for collateral in line with the length of time the relationship. This will certainly have an impact on higher risks of the bank. Hernandez-Canovas and MartınezSolano's (2010) study supports the claim that small medium enterprises (SMEs) with longer bank relationships are more likely to receive a loan than SMEs with shorter bank relationships, and those longer relationships lead to higher interest rates. They also found that SMEs that maintained two bank relationships had the lowest costs.

Other studies focus on the relationship lending is on aspects of lenders (banks and financial institutions), in which the research related to this theme focuses on the size of banks and characteristics of loan officers. Small banks turned out to be more receptive to the benefits of an ongoing relationship and long with the borrower, while the big banks with a portfolio of funds and more diverse product the bargaining power is higher, so it does not focus on deeper relationships with borrowers (De la Torre, et al., 2010)

Research conducted by Cole (1998) examines the impact of pre-existing relationship before the loan is approved between the company and the bank. The conclusion of this study is that companies with multiple relationship or associated with many banks have a tendency to loan approval is not submitted; in the sense of a company that has an intense relationship with only one bank has a tendency loan will be approved. Multiple relationships are one indication that the company has a low level of relationship lending.

The role of loan officers in relationship lending investigated by Uchida et al. (2011), and found that loan officers play a very important role in building relationships with borrowers. In this study, the researchers found that the close relationship between loan officer and the borrowers can improve the availability of soft information or qualitative characteristics information for banks. The study also proved that the loan officer in small bank has a greater role than the loan officers on large banks in an effort to collect relevant information about qualitative characteristics.

The previous study that examines the relationship between relationship lending on lending decision making, especially credit worthiness also presented a different findings. The study by Petersan and Rajan (1994), Cole (1998) and Behr et al. (2012) found that the relationship lending has a major role on credit worthiness, whereas on the other hand research conducted by Campanella et al. (2013), Uchida et al. (2012) and De La Torre et al. (2010) stated that the relationship lending has no impact on the credit worthiness especially on large banks.

The results of this review show inconsistencies in the results of the empirical evidence on the role of relationship lending on lending decision making. This raises a presumption that there are variables mediating the correlation between these two constructs. In line with the conclusions of correlation between borrower characteristic and lending decision making, allegedly there are other factors that play a role on the correlation between relationship 
lending and lending decision making, including the factor of organization, type of the proposed loan and the characteristics of the loan officer.

\section{CONCLUSION}

The role of borrower characteristic information is very important on lending decision making. Research on this subject reveals a different level of importance of the two types of borrower characteristic information. Some research shows that the qualitative characteristics have a huge effect on the lending decision making (Beaulieu, 1996; Boot, 2000; Wilson et al., 2007; Soares et al., 2011; Bartoli et al., 2013; Buttner and Rosen, 1988), but other research proves the quantitative characteristic also has a major role in the lending decision making (Danos et al., 1989; Beaulieu, 1996; Price, 1992; Grunert, et al., 2005; Bruns and Fletcher, 2008; Soares et al. , 2011). Different result showed by Grojer and Catasus (2003) as well as Tornberg and Hemlin (2013), they revealed that qualitative characteristics are not a major concern in the lending decision making.

The results of this review led to speculation that on different circumstances, the role qualitative and quantitative characteristics on lending decision making will generate different findings. The conditions and circumstances, including the condition of organization's management, such as the size of the bank (Campanella et.al. 2013; Uchida et al. 2012), policy management, ownership, the type of the proposed loan and the conditions of the loan officer. This theme becomes important to be studied in advanced research related to the role of borrower characteristics and the lending technology on lending decision making, in order to give a deeper understanding of the study on this theme.

The influence of relationship lending on lending decision making also showed different findings. Some research found that relationship lending plays a major role on lending decision making (Petersen and Rajan, 1994; Berger and Udell 1995; Jimenez and Saurina 2004; Cole, 1998; Degryse and Van Cayseele 2000; Hernandez-Canovas and MartinezSolano's 2010), while others research finds that relationship lending does not have a major role on lending decision making (Campanella et al., 2013; Uchida et al., 2012; De La Torre et al., 2010). Inconsistency of these findings also raises a presumption that in certain condition and situations, there are differences in the role of relationship lending on lending decision making. This condition can occur on the type and size of the bank, organization management conditions, the type of the proposed loan and the conditions of the loan officer.

The focus of research on various conditions that might have an impact on the role of the borrower characteristics and relationship lending on lending decision making focused on the role of some factors on loan officers such as intuition, expertise and trust. Research from Hensman and Sadler Smith (2011) found that loan officers use an intuitive approach to lending decision making, despite the approach of this intuition is used as a complement of a rational approach. More experienced, older and more knowledgeable participants tended to be more confident in their ability to make valid decisions using intuitive reasoning. Lipshitz and Shulimovitz (2007) found that gut feeling contributed to the credit decision and that loan officers valued gut feeling as a valid cue for making sound decisions. Andersson (2004) reported that experienced loan officers acquired more information about their clients than novices and also spent more time evaluating the material before they made their decisions. However, experienced loan officers did not differ from novices in consistency regarding credit decisions between different clients.

Banking research that examines the bank-borrowers relationship, led to finding that trust plays an important role in reducing agency costs so as to improve access to credit for borrowers, lower transaction costs, lower level of assurance, and also reduce personal guarantee (personal guarantee) (Howorth, 2006). A study on the influence of the borrower's characteristics on trust has not been done. The concepts introduced by Luhman (1979) states that basic past relationship (historical) as the basis for building trust. But on the shortterm relationship, trust is usually based on the information received and the estimation of risk that must be borne. In conjunction with the characteristics of the borrower, which is this characteristic is the information received by the loan officer, then in accordance with the 
concepts put by Luhman (1979), can be argued that the borrower's characteristics information, both qualitative and quantitative can influence loan officers trust.

A theory proposed by Seal and Vincent Jones (1997) states that the accounting information of borrowers for that matter quantitative characteristic will increase trust of loan officers. A research conducted by Harhof and Korting (1998) and Howorth and Moro (2012) proves that the value of the collateral which is part of quantitative characteristic of borrower may affect the trust of loan officers.

The concept proposed by Seal (1998) stated that lending relationships have an influence on loan officers trust. Trust can confirm or fill the lack of uncertainties that arise after the information is received and evaluated by the loan officer (Moro and Fink, 2012). In relation to the relationship lending, trust can compensate for the asymetry of information so that the lending decision making can be more precise and better.

Effect of trust in the lending decision making, especially on borrower-lender relationship in banking, has not been studied in depth. Studies conducted by Moro and Fink (2012) found that trust plays an important role in credit worthiness. This study proved that the higher the trust will improve access to credit of borrowers in terms of increasing the credit worthiness. This research has not been thoroughly investigated the role of borrowers characteristics information and relationship lending in relation to trust. Themes related to the role of trust in borrowerlender relationship in the lending decision making becomes something important to do.

\section{REFERENCES}

1. Andersson, P., 2000. Expertise in credit granting - studies on judgment and decisionmaking behavior. Doctoral thesis, Stockholm University, Stockholm.

2. Bartoli, F., Ferri, G., Murro, P., and Rotondi, Z., 2013. SME Financing and the Choice of Lending Technology in Italy: Complementaryty or Substitutability. Journal of Banking and Finance. Vol 37, pp 5476-5485.

3. Beaulieu, P. 1994. Commercial Lenders' Use of Accounting Information in Interaction with Source Credibility. Contemporary Accounting Research. pp. 557-585.

4. Beaulieu, P. 1996. A Note on the Role of Memory in Commercial Loan Officers' Use of Accounting and Character Information. Journal of Accounting, Organizations and Society.Vol 21.No.6 p.516

5. Behr, P., Entzian, A., and Güttler, A. 2011. How do lending relationships affect access to credit and loan conditions in microlending? Journal of Banking and Finance.

6. Berger, A.N. and Udell, G. 1995. Relationship Lending and Lines of Credit in Small Firm Finance, The Journal of Business, The University of Chicago Press, Vol 68, No.3.

7. Berger, A.N. and Frame, S. 2005. Small Business Credit Scoring and Credit Availability, Federal Reserve Bank of Atlanta Working Paper Series.

8. Berger, A.N. and Black, L.K. 2011. Bank Size, Lending Technologies, and Small Business Finance. Journal of Banking and Finance 35, 724-735

9. Berger, A.N. and Udell, G. 2006. A More Complete Conceptual Framework for SME Finance. Journal of Banking and Finance, Vol.30, pp. 2945-2966.

10. Boot, A. 2000. Relationship Banking: What Do We Know ? Journal of Financial Intermediation, Vol 9. pp 7-25.

11. Bruns, V. and Fletcher, M. 2008. Banks' risk assessment of Swedish SMEs, Venture Capital, Vol. 10 No. 2, pp. 171-94.

12. Buttner, E.H., Rosen, B. 1988. Bank loan officers' perceptions of the characteristics of men, women and successful entrepreneurs. Journal of Business Venturing, Vol. 3, pp. 249-258.

13. Campanella, F., Del Giudice, M., and Della Peruta, M.R. 2013. The Role of Information in The Credit Relationship. Journal of Innovation and Entrepreneurship, Vol 2.

14. Catasu's, B. and Gro jer, J.E. 2003. Intangibles and credit decision: results from an experiment. European Accounting Review, Vol. 12 No. 2, pp. 327-55.

15. Cole, R.A. 1998. The importance of relationships to the availability of credit. Journal of Banking \& Finance Vol 22, pp 959-977 
16. Cole R.A, Goldberg L.G, and White, L.J. 2004. Cookie cutter versus Character, The Micro Structure of small business lending by large and small bank. Journal of Financial and Quantitative Analysis.

17. Crigger, J. 1975. An Ocean of C's. Journal of Commercial Bank Lending. pp 2-8

18. Danos, P., Holt, D.L., and Imhoff, E.A.,Jr. 1989. The Use of Accounting Information in Bank Lending Decisions. Pergamon Press, Journal of Accounting, Organizations and Society, Vol 14, No. 3, pp 235-246.

19. De la Torre, A., Peria, M.S.M., and Smuckler, S. 2010. Bank Involment with SME's: Beyond Relationship Lending. Journal of Banking and Finance.

20. Dijksterhuis, A. and Nordgren, L.F. 2006. A theory of unconscious thought. Perspectives on Psychological Science, Vol. 2 No. 1, pp. 95-109.

21. Elsakit, O. and Worthington, A. 2013. Using Environmental and Social Information on Lending Decision. International Journal of Economics and Finance. 1(5), pp 112-120

22. Elyasani, E. and Goldberg, L. 2004. Relationship lending, a survey of literature. Journal of Economic and Business.

23. Gigerenzer, G. 2007. Gut Feelings - Short Cuts to Better Decision Making. London.

24. Grunert, J., Norden, L., and Weber, M. 2005. The Role of Non Financial Factors for Internal Credit Rating. Journal of Banking and Finance Vol. 29, p 511

25. Hand, D.J. and Henley, W.E. 1997. Statistical classification methods in consumer credit scoring: a review. Journal of The Royal Statistical Society, Vol. 160 No. 3, pp. 523-41.

26. Harhoff, D., Körting, T. 1998. Lending relationships in Germany - empirical evidence from survey data. Journal of Banking \& Finance Vol 22, pp 1317-1353.

27. Hensman, A. and Sadler-Smith, E. 2011. Intuitive decision making in banking and finance. European Management Journal, Vol. 29 No. 1, pp. 51-66.

28. Hernandez-Canovas, G. et al 2010. Relationship lending and SME financing in the continental European bank-based system. Small Business Economics 34, pp 465-482.

29. Hogarth, R.M. and Karelaia, N. 2007. Heuristic and linear models of judgment: matching rules and environments. Psychological Review, Vol. 114 No. 3, pp. 733-58.

30. Howorth, C. and Moro, A. 2012. Trustworthiness and the cost of credit: an empirical study of SMEs and small banks in Italy. Small Business Economics Vol 39, pp 161-177.

31. Howorth, C. and Moro, A. 2006. Trust Within Entrepreneur Bank Relationship: Insight from Italy. Entrepreneurship Theory and Practice. Baylor University.

32. Kahneman, D. and Tversky, A. 1979. Prospect theory: an analysis of decision under risk. Econometrica, Vol. 47 No. 2, pp. 263-91.

33. Kahneman, D., Slovic, P. and Tversky, A. 1982. Judgment under Uncertainty: Heuristics and Biases. Cambridge University Press, Cambridge, MA.

34. Klein, G. 2008. Naturalistic decision making, Human Factors. The Journal of the Human Factors and Ergonomics Society, Vol. 50 No. 3, pp. 456-60

35. Leland, H. and Pyle, D. 1977. Information asymmetries, financial structure, and financial intermediaries. Journal of Finance 32: pp.371-387.

36. Lehman, B. 2003. Is it Worth The While? The Relevance of Qualitative Information on Credit Rating. Working Paper, University of Konstanz, Germany.

37. Lehman, E. and Neuberger, D. 2001. Do lending relationship matter? Evidence from bank survey data in Germany. Journal of Economic Behaviour and Organisation.

38. Lipshitz, R. and Shulimovitz, N. 2007. Intuition and emotion in bank loan officers' credit decisions. Journal of Cognitive Engineering and Decision Making, 1(2), pp. 212-33.

39. Luhmann, N. 1979. Trust and Power. John Wiley \& Sons, Chichester.

40. Maines, L.A. 1995. Judgment and decision-making research in financial accounting: a review and analysis. In Ashton, R.H. and Ashton, A.H. (Eds), Judgment and Decisionmaking Research in Accounting and Auditing, Cambridge University Press. pp. 76-101.

41. Mayer, R.C., Davis, J.H. and Schoorman, F.D. 1995. An integrative model of organizational trust. Academy of Management Review, Vol. 20 No. 3, pp. 709-734.

42. Mason, C. and Stark, M. 2004. What do investors look for in a business plan?. International Small Business Journal, Vol. 22 No. 3, pp. 227-48. 
43. Moro, A. et al 2012. Trust and The Demand of Personal Collateral in SME's-Bank Relationship. Prosiding Paper Conference on Sustainable Entrepreneurship and Inclusive Interventions: Global Perspective. Lancashire Business School.

44. Moro, A. and Fink, M. 2012. Loan Managers' Trust and Acces for SMEs. Journal of Banking and Finance. Vol 37. pp. 927-936.

45. Newell, B.R. and Rakow, T. 2011. Revising beliefs about the merits of unconscious thought: evidence in favor of the null hypothesis. Social Cognition, 6(29), pp. 711-26.

46. Newell, B.R., Wong, K.Y., Cheung, J.C.H. and Rakow, T. 2009. Think, blink or sleep on it? The impact of modes of thought on complex decision making. Quarterly Journal of Experimental Psychology, Vol. 62, pp. 707-32.

47. Nordgren, L.F. and Dijksterhuis, A. 2009. The devil is in the deliberation: thinking too much reduces preference consistency. Journal of Consumer Research, 1(36), pp. 39-46.

48. Petersen, M.A. 2004. Information: Hard and Soft. Working Paper, Kellog School of Management, Northwestern University.

49. Petersen M.A and Rajan R.G. 1994. The Benefit of lending relationship: evidence from small business data. Journal of Finance.

50. Price, C.E. 1992. Accounting Information and Loan Quality Assesment: An Investigation of Decision Process. Dissertation on Accounting. Texas A\&M University.

51. Ralf, E. 2002. Empirical determinans of relationship lending. Journal of Financial Intermediation.

52. Ramakrishnan, R.T.S. and Thakor, A. 1984. Information Reliability and a Theory of Financial Intermediation. Review of Economic Studies Vol.51, pp. 415-432

53. Seal, W.B. and Vincent-Jones, P. 1997. Accounting and trust in the enabling of long-term relations. Accounting, Auditing \& Accountability Journal, Vol. 10 No. 3, pp. 406-31.

54. Seal, W.B. 1998. Relationship Banking and the Management of Organisational Trust, International Journal of Bank Marketing, MCB University Press. Vol 16/3, pp102-107.

55. Simon, H.A. 1955. A behavioral model of rational choice. Quarterly Journal of Economics, Vol. 69 No. 1, pp. 99-118.

56. Simon, H.A. 1956. Rational choice and the structure of the environment. Psychological Review, Vol. 63 No. 2, pp. 129-38.

57. Soares, J.O. et al 2011. Quantitative vs Qualitative Criteria for Credit Risk Assesment. Frontiers in Finance and Economics Vol. 8, pp 69-87.

58. Sutter, P.J. 2007. A Quantitative Study of The Collection of Soft Information by Small Community Banks; Building Sustainable Competitive Advantage. Dissertasion-Falls School of Business, Anderson University, Ohio USA

59. Thomas, L.C. 2000. A survey of credit and behavioural scoring: forecasting financial risk of lending to consumers. International Journal of Forecasting, Vol. 16 No. 2, pp. 149-72.

60. Tronberg, C.C. and Hemlin, S. 2012. Bankers lending decision making: a psychological approach. Managerial Finance, Vol. 38 No. 11, 2012 pp. 1032-1047

61. Tronberg, C.C. and Hemlin, S. 2013. Lending Decision Making in Bank: a Critical Incident Study of Loan Officer. European Management Journal.

62. Tversky, A. and Kahneman, D. 1974. Judgment under uncertainty: heuristics and biases. Science, Vol. 185 No. 4157, pp. 1124-31.

63. Uchida, H., Udell, G., and Nobuyoshi, Y. 2006. SME Financing and the Choice of Lending Technology. RIETI Discussion Paper Series 06-E-025. Research Institute of Economy, Trade, and Industry.

64. Uchida, $H$. et al 2008. How do Japanese banks discipline small and medium-sized borrowers? In Choi, J., Dow, S. (Eds.), Institutional Approach to Global Corporate Governance: Business Systems and Beyond. Emerald Group Publishing Limited.

65. Uchida, H., Udell, G., and Nobuyoshi, Y. 2012. Loan Officer and Relationship lending to SME's. Journal of Financial Intermediation.

66. Udell, G.F. 2007. What's in a Relationship? The Case of Commercial Lending. Business Horizons. Kelley School of Business. Vol.51. pp 93-103

67. Wilson, F. et al 2007. Bank loan officers' perceptions of business owners: the role of gender. British Journal of Management, Vol. 18 No. 2, pp. 154-71. 